\title{
PESTICIDE EXPOSURE INDEX: PRACTICES AMONG WOMEN FROM AN AGRICULTURAL COMMUNITY IN SOUTHEAST MEXICO
}

\author{
Norma PÉREZ-HERRERA ${ }^{1 *}$, Mayra VERA-AVILÉS ${ }^{1}$, Teresa CASTILLO-BURGUETE $^{2}$, \\ Javier PERERA-RIOS ${ }^{1}$, Ramón ESPERÓN-HERNÁNDEZ ${ }^{3}$, Aurora Elizabeth ROJAS-GARCÍA ${ }^{4}$, \\ Irma Martha MEDINA-DÍAZ ${ }^{4}$ and Betzabet QUINTANILLA-VEGA ${ }^{5}$
}

${ }^{1}$ Unidad Interinstitucional de Investigación Clínica y Epidemiológica, Facultad de Medicina, Universidad Autónoma de Yucatán, México

${ }^{2}$ Departamento de Ecología Humana, Centro de Investigación y de Estudios Avanzados del IPN, Unidad Mérida, Yucatán, México

${ }^{3}$ Facultad de Medicina, Universidad Autónoma de Yucatán, México

${ }^{4}$ Laboratorio de Contaminación y Toxicología Ambiental, Secretaría de Investigación y Posgrado, Universidad Autónoma de Nayarit

${ }^{5}$ Departamento de Toxicología, Centro de Investigación y de Estudios Avanzados del IPN, Unidad Zacatenco, México

*Author for correspondence: norma.perez@correo.uady.mx

(Received January 2017; accepted June 2018)

Key words: women, exposure index, pesticides

\begin{abstract}
The adverse effects of pesticides on public health have been well documented in different populations across the world. Families of agricultural workers, particularly their wives, face pesticide exposures through a number of complex patterns even when they do not directly engage in agricultural work. Nonetheless, these patterns of exposure among women in agricultural communities remain understudied. Unfortunately, in Mexico there are no studies examining these patterns yet. In consequence, the main goals of this study were to: 1) evaluate pesticide exposure in a rural community of Southeast Mexico, 2) examine the patterns of environmental and para-occupational pesticide exposure, and 3) document the para-occupational and environmental pesticide exposure among women who are not agricultural workers but have an agricultural family or are wives of agricultural workers. We conducted a cross-sectional study of 78 women who did not themselves participate in any agricultural activity, but lived in an agricultural community. Questionnaires and interviews were used to construct a Pesticide Exposure Index (PEI) estimating the degree of pesticide exposure among women from agricultural families and wives of agricultural workers. Through the PEI we showed that women living in agricultural communities using pesticides are inherently exposed to a certain level of pesticides. With the PEI we showed that women from agricultural families, especially wives of agricultural workers, have a long-term para-occupational pesticide exposure that should not be underestimated because they are not agricultural workers.
\end{abstract}

Palabras clave: mujeres, índice de exposición, plaguicidas 


\section{RESUMEN}

Los efectos adversos de los plaguicidas en la salud pública han sido documentados en poblaciones de distintas partes del mundo. Las familias de agricultores y en particular las esposas de agricultores enfrentan complejos patrones de exposición a plaguicidas, aunque no trabajen en la agricultura. Éstos han sido poco estudiados y en México todavía no hay trabajos que los muestren. Por ello, los objetivos de este estudio fueron: 1) evaluar el nivel de exposición a plaguicidas en una comunidad agrícola, 2) conocer los patrones de exposición ambiental y paraocupacional, y 3) documentar la exposición paraocupacional y ambiental a plaguicidas entre mujeres que no trabajan en la agricultura pero que provienen de una familia de agricultores o son esposas de agricultores. Se realizó un estudio transversal en el que participaron 78 mujeres que no trabajan en la agricultura. Se aplicó un cuestionario por entrevista y se construyó un índice de exposición a plaguicidas (IEP) estimando la magnitud de la exposición en mujeres de familia agrícola y esposas de agricultores. A través del IEP, mostramos que las mujeres que viven en una comunidad agrícola que usa plaguicidas tienen, de manera inherente, algún grado de exposición ambiental a éstos. Con ayuda del IEP demostramos que las mujeres de familia agrícola, en particular las esposas de los agricultores, tienen una exposición paraocupacional de largo plazo que no debería subestimarse por no ser trabajadoras agrícolas.

\section{INTRODUCTION}

Pesticides are among the most widely distributed pollutants in the world. There are over a thousand active principles used as pesticides, herbicides, and fungicides. And although they have important benefits for agriculture and for the control of infectious diseases, occupational and environmental pesticide exposures are associated with chronic public health problems (Mostafalou and Abdollahi 2013). Issa et al. (2010) observed a para-occupational exposure pathway in family members with an agricultural worker. Women living with agricultural workers can be exposed to pesticides through their storage at home and by the interaction with contaminated clothes and agricultural implements (Gladen et al. 1998). Deziel et al. (2015) evaluated the non-occupational patterns of pesticide exposure among women living in agricultural zones in North America. Thirty-five studies published between 1999 and 2013 found reasonable evidence of para-occupational and agricultural drift exposure to pesticides among women. These studies also showed minor exposure to pesticides from residential use, and a limited influence of different hygiene practices on the levels of pesticide exposure (Deziel et al. 2015). Nonetheless, these complex scenarios carry with them important limitations in the evaluation of the degree of exposure to pesticides.

Additionally, it is costly to determine the pesticide exposure (through urine metabolites) in women in agricultural communities given that the biological determination of a single pesticide in a cross-sectional study might not necessarily be a reflection of a chronic exposure. Moreover, individuals are often exposed to a mixture of pesticides rather than only one. Because of this, researchers have relied on the construction of exposure indices or proxies to estimate the levels of pesticide exposure (Pérez-Herrera et al. 2008, Jurewicz et al. 2012, Beard et al. 2013). The estimate of pesticide exposure in rural populations, including the wives of agricultural workers, has been described in the literature (Alavanja et al. 1996, Gladen et al. 1998, Kirrane et al. 2004, Issa et al. 2010, Jurewicz et al. 2012). However, in Mexico, the scenarios of non-occupational pesticide exposure of women have not yet been well documented. Knowing more about this problem could help laying the background for future research on the effects of nonoccupational pesticide exposure in Mexico, and its consequences on the health of agricultural workers' wives. Para-occupational pesticide exposure could well be a critical and underestimated public health problem. This study can also help to generate new health education strategies and policies to changing practices and reducing the risks of health problems among agricultural workers' wives. For this reason, the main objectives of the study were to: (1) evaluate pesticide exposure, (2) understand environmental and para-occupational patterns of exposure, and (3) document the para-occupational and environmental pesticide exposure among women who are not agricultural workers but have an agricultural family or are wives of agricultural workers. Our results were fed-back to the community to prevent damage from 
exposure to pesticides. This study emerged out of a previous collaboration between the community of Muna and our research team. In fact, the research agenda was first proposed by members of the community after our first initial collaboration with them in 2008 (Pérez-Herrera et al. 2008). As a result of our time together, their collaboration significantly helped to enrich our research goals.

\section{Study population}

\section{METHODS}

A cross-sectional survey and descriptive study was conducted in Muna, a rural town in Southeast Mexico between 2012 and 2013. In the community of Muna, pesticide use constitutes a common activity of their agricultural work and daily lives. The municipality of Muna is located $53 \mathrm{~km}$ from Merida city, the capital of the state of Yucatán. In 2010, the municipality had 12 336 people, most of them of Yucatecan-Maya heritage (INEGI 2010). Out of the 833 agricultural production units using pesticides in the state of Yucatan, 103 can be found in Muna (INEGI 2010). Several crops are cultivated in Muna: habanero chili (Capsicum chinense Jacq.), maradol papaya (Carica papaya), tomato (Solanum lycopersicum L.), maize (Zea mays L.), watermelon (Citrullus lanatus), and sweet orange (Citrus sinensis L.). We presented the objectives of our study to the community through a number of events organized by the municipal authorities and the rural clinic. Women interested in participating received a home visit. During these visits, women referred to other potential participants, leading us to employ a snowball sampling technique (Romero et al. 2003, Saavedra 2016). According to a previous study conducted in the same community with farmers (Pérez-Herrera et al. 2008), our aim was to have the involvement of 50-70 women. However, a total of 78 unrelated women accepted to participate in the study. The inclusion requirement was to have a minimum residence time of one year in the municipality of Muna. During the entire length of the study, we remained in close contact with all the participants until the different stages of data collection was completed and the focal groups for discussion, presentation of results, and feedback had ended.

Our research team had previously reported that PON1Q192R genetic polymorphism modified the effects of organophosphorus pesticide on semen quality and DNA integrity of agricultural workers living in this community (Pérez-Herrera et al. 2008). In terms of the handling of pesticides by agricultural workers, $58 \%$ of men stored pesticides at home; this practice established an important possibility of paraoccupational exposure for their wives and families, which deserves more attention. We developed focal groups to present our results to the individuals participating in the study. Agricultural workers in Muna raised concerns about their spouses being exposed to pesticides by indirect ways through storing them at home and washing their clothes contaminated with pesticides (Pérez-Herrera et al. 2013).

All women gave their informed consent to participate in our study responding the questionnaire. The study was approved by the Ethical Research Review Board of the School of Medicine at the Autonomous University of Yucatan (UADY).

\section{Questionnaires}

Extensive structured interviews were conducted to assess the levels of pesticide exposure and health problems. The questionnaires were similar to those applied by Alavanja et al. (1996), Gladen et al. (1998), Kirrane et al. (2004), and Issa et al. (2010). They gathered information on socio-demographic characteristics, pesticides use practices at home and work, personal protection equipment, direct and indirect patterns of potential pesticides exposure (environmental, occupational, para-occupational and residential contact), women's and agricultural workers' hygiene practices, levels of smoking and alcohol consumption, and any other medical condition of the interviewees.

\section{Assessing the exposure: pesticide exposure index (PEI)}

In order to understand the degree of pesticide exposure, we constructed a PEI as a proxy for pesticide exposure among residents of Muna by the sum of environmental, para-occupational, and residential exposures among people from the municipality. We also used this index to establish differences in exposure between: (1) wives of agricultural workers vs. (2) wives of non-agricultural workers; and (3) women with agricultural families vs. and (4) women with non-agricultural families. Initially, we performed a stage of elimination of variables from the questionnaires; all unanswered, null, or negative variables were excluded for the index. We only considered the questions that were answered by participants. All questions used for the development of the index were answered with a value different from zero. The variables used for the PEI were classified in the following groups: past occupational exposure (POE), past para-occupational exposure from living with an agricultural family (PPE), current environmental 
exposure (CEE), current para-occupational exposure (CPE), and para-occupational exposure from washing contaminated clothes (POW). Finally, the PEI was developed with the sum of the values from the appropriate groups. In total, 78 variables were used: 75 qualitative ones (dichotomous, two level variables, zero and one) (Montgomery et al. 2006), and three quantitative ones (see Table I).

\section{Data analysis}

Descriptive statistics was obtained for all variables. Categorical variables were expressed as proportions; normal distribution was examined for numerical variables and means \pm standard deviation or geometric means (range) were used accordingly. Student t-test or Mann-Whitney U test were employed to compare the exposure between: (1) wives of agricultural workers vs. (2) wives of non-agricultural workers; (3) women from agricultural families vs. (4) women from non-agricultural families. All analyses were carried out using STATA v. 10 (STATA, Corp.) and the significance for all analyses was set at a $p$ value of $<0.05$.

\section{RESULTS AND DISCUSSIONS}

Environmental and para-occupational exposure to pesticides among women who do not work in agriculture but live in agricultural communities is an area of study that has received relatively little attention in the literature. In this study, we show some patterns of environmental and para-occupational pesticide exposure via residential use and various hygiene practices

TABLE I. VARIABLES EMPLOYED IN THE CONSTRUCTION OF THE PESTICIDE EXPOSURE INDEX

\begin{tabular}{|c|c|c|}
\hline Group & Variables & Level \\
\hline POE & $\begin{array}{l}\text { Handles pesticides, works in the field: sowing, harvesting, preparing pesticides, combining different } \\
\text { pesticides, fumigating, fertilizing, raising animals }\end{array}$ & $\begin{array}{l}\text { Yes }=1 \\
\text { No }=0\end{array}$ \\
\hline \multirow{2}{*}{ POW } & $\begin{array}{l}\text { Washes clothes: washes clothes at home, washes clothes by hand, washes pesticide contaminated clothes } \\
\text { with normal clothes }\end{array}$ & $\begin{array}{l}\text { Yes }=1 \\
\text { No }=0\end{array}$ \\
\hline & Wears some sort of protection while washing contaminated clothes & $\begin{array}{l}\text { Yes }=1 \\
\text { No }=0\end{array}$ \\
\hline \multirow{3}{*}{$\mathrm{CPE}$} & $\begin{array}{l}\text { Husband, father, father in law, brother, uncle, mother, cousins, or another family member is an agricultural } \\
\text { worker. The family member manages a field: sowing, harvesting, preparing pesticides, fumigating. Helps } \\
\text { a family member to work in the field: sowing, harvesting, preparing pesticides, fumigating, applying } \\
\text { home-made pesticides, applying industrial pesticides. Consumption of harvested products }\end{array}$ & $\begin{array}{l}\text { Yes }=1 \\
\text { No }=0\end{array}$ \\
\hline & $\begin{array}{l}\text { A family member wears protection when doing agricultural chores, and leaves contaminated boots } \\
\text { outside the house }\end{array}$ & $\begin{array}{l}\text { Yes }=1 \\
\text { No }=0\end{array}$ \\
\hline & $\begin{array}{l}\text { Number of years that a family member has worked in agriculture. Number of years living with an } \\
\text { agricultural worker }\end{array}$ & Years \\
\hline PPE & $\begin{array}{l}\text { Was born in an agricultural family. Father, mother, grandfathers, brothers, uncles, or cousins work in } \\
\text { agriculture, lives in an agricultural area, and uses pesticides }\end{array}$ & $\begin{array}{l}\text { Yes }=1 \\
\text { No }=0\end{array}$ \\
\hline \multirow[t]{3}{*}{ CEE } & $\begin{array}{l}\text { Uses homemade agricultural pesticides. Uses homemade agricultural pesticides in the house. Keeps pets } \\
\text { in the house, keeps pesticides either inside or outside the house. Uses pesticides inside the house, in } \\
\text { some part of their land, in its surroundings, in the garden, or in the backyard. Neighbors use pesticides; } \\
\text { neighbor's family is a family of an agricultural worker. Spends time in the house of an agricultural } \\
\text { worker. There are pests in the house or garden. Keeps agricultural pesticides at home. Has fumigated, } \\
\text { used pesticides, worked with a mix of pesticides }\end{array}$ & $\begin{array}{l}\text { Yes }=1 \\
\text { No }=0\end{array}$ \\
\hline & Wears protection when handling pesticides & $\begin{array}{l}\text { Yes }=1 \\
\text { No }=0\end{array}$ \\
\hline & Distance between house and the field & Kilometers \\
\hline PEI & $\mathrm{PEI}=\mathrm{POE}+\mathrm{POW}+\mathrm{CPE}+\mathrm{PPE}+\mathrm{CEE}$ & Numerical value \\
\hline
\end{tabular}

POE: past occupational exposure, POW: para-occupational exposure from washing contaminated clothes, CPE: current para-occupational exposure, PPE: past para-occupational exposure, CEE: current environmental exposure, PEI: pesticide exposure index 
among a group of 78 women in a Mayan community of Mexico. While there are other studies focusing on the patterns of pesticide exposure in agricultural workers, as far as we know, this work is the first study focused on the pattern of para-occupational exposure of women living in an agricultural setting but not directly participating in agricultural work.

\section{General characteristics of the study population}

Some general characteristics of the 78 women that participated in this study are displayed in table II. The participants were all in a reproductive age (32.79 \pm 5.39 years) and had an average of less than nine years of schooling. This is relevant considering the differences between women in the present study and the population described in the Agricultural Health Study (AHS), where the average age and level of education were higher (48.4 years, and up to high school), as described by Alavanja et al. (1996). The characteristics of our study participants are also different from the wives of agricultural workers described by Kirrane et al. (2004) (46 yrs. and education up to high school between 40-42\%). This suggests that participants in our study have a greater vulnerability, especially because they are still at reproductive

TABLE II. CHARACTERISTICS OF PARTICIPATING WOMEN $(\mathrm{n}=78)$

\begin{tabular}{lc}
\hline Characteristic & Value \\
\hline Age (years, mean $\pm \mathrm{SD})$ & $32.79 \pm 5.39$ \\
Body mass index $\left(\mathrm{kg} / \mathrm{m}^{2}\right.$, mean $\left.\pm \mathrm{SD}\right)$ & $29.02 \pm 5.11$ \\
Underweight $(\%)$ & 3 \\
Normal $(\%)$ & 18 \\
Overweight $(\%)$ & 42 \\
Obese (\%) & 37 \\
Smoker (\%) & 15 \\
Alcohol drinker (\%) & 56 \\
Number of years of education (mean $\pm \mathrm{SD})$ & $8.56 \pm 3.33$ \\
Mayan language speaker (\%) & 41 \\
Housewife (\%) & 71 \\
Works applying pesticides in control vectors & 1 \\
Born in Yucatan (\%) & 97 \\
Born in Muna, Yucatan (\%) & 90 \\
Born in an agricultural family (\%) & 68 \\
Member of an agricultural family (\%) & 62 \\
Member of the family who works as & \\
a farmer (\%) & \\
Husband & 40 \\
Father & 13 \\
Father in law & 11 \\
Married (\%) & 95 \\
Women with children (\%) & 100 \\
Number of children (median and range) & $2(1-6)$ \\
\hline
\end{tabular}

age and thus the effects of pesticide exposure on their reproductive health are of greater consequences.

None of the participants in the study directly worked in agriculture. Most women were housewives $(71 \%)$, and one worked applying pesticides in control vectors of dengue (as part of a public health program). The rest of participants worked in different activities, all unrelated to agricultural work. Fortyone participants were bilingual (Mayan language and Spanish) speakers. Almost all participants (90\%) were born in Muna, Yucatan. Over $60 \%$ were born in agricultural families or lived with an agricultural worker. Ninety-five percent were married, and $38 \%$ were wives of agricultural workers. All participants had kids; on average each woman had two children, ranging from one to six.

\section{Pesticides: handling practices and environmental exposure among the population of Muna}

A complex scenario of pesticide exposure was observed among women who live in this agricultural community and participated in the study, even when they were not agricultural workers. We identified environmental and non-occupational residential pesticide exposure. The uses of pesticides at home as well as the environmental exposure to pesticides are shown in Table III. The results show that all participants in the study were potentially exposed (either directly or indirectly) to pesticides via several pathways, simply by living in a rural community where agriculture is as lifestyle.

First of all, the use of pesticides at home was a frequent practice. Almost all women declared using pesticides at home, mainly for insects $(94 \%$ of women used domestic products, while $20 \%$ used agricultural pesticides). Similar results were reported by Kirrane et al. (2004) and Samanic et al. (2005) in the AHS, who described the use of pesticides by spouses of applicators at their homes, gardens, and with pets, although recently Lerro et al. (2015) reported a frequency of pesticide use at home and garden by the spouses of pesticide applicators in the AHS of less than $30 \%$. In addition, we also observed that one of every two participants lived near a family of agricultural workers or in close proximity to neighbors using pesticides in their house, patio, or garden. Finally, one of each three women declared having spent time in an agricultural worker's house.

\section{Pesticides: storage at home}

Storing pesticides at home was a practice observed in $60 \%$ of the study population (Table IV). Regarding the type of pesticides stored, they were 
TABLE III. PATTERNS OF PESTICIDE EXPOSURE AMONG WOMEN IN AN AGRICULTURAL COMMUNITY $(\mathrm{n}=78)$

\begin{tabular}{lc}
\hline Pesticide exposure & $\begin{array}{c}\text { Frequency } \\
(\%)\end{array}$ \\
\hline $\begin{array}{l}\text { Type of pesticides used at home } \\
\text { Household pesticides }\end{array}$ & $94^{*}$ \\
Agricultural pesticides & $20^{*}$ \\
Washes hands after using pesticides at home, patio & \\
or garden & 86 \\
Specific location in the house where pesticides are & \\
used & $77^{*}$ \\
Inside the house & $29^{*}$ \\
Patio & $23^{*}$ \\
$\quad$ Around the house & $10^{*}$ \\
$\quad$ Garden & 18 \\
Uses pesticides on pets or farm animals & 56 \\
Fumigation in the house & $82^{* *}$ \\
Fumigation by a technical specialist & $11^{* *}$ \\
Fumigation by the husband & $5^{* *}$ \\
Fumigation by the participant & $2^{* *}$ \\
Other & 59 \\
Has neighbors from an agricultural family & \\
Living in the proximity of neighbors using pesticides & \\
in the house, patio or garden & 50 \\
Spending time in a farmer's home & 33 \\
\hline
\end{tabular}

* Percentage of homes in which pesticides are used (70 of 78)

** From the houses that were fumigated

mostly insecticide and pesticides for domestic use; agricultural pesticides were stored in $62 \%$ of homes. Almost all women married to an agricultural worker or living with a family of agricultural workers $(\mathrm{n}=$ 47) reported storing pesticides in a special location in their homes. Among them, a storehouse outside the main home was the most common location for keeping the pesticides. However, over $30 \%$ of the women declared storing pesticides inside their houses, using the bathroom as the most frequent storage location. Either outside or inside the houses, pesticides were often located at the highest part of a room as a general rule of precaution. Nonetheless, pesticides were at times stored in areas commonly used by the family such as the bathroom or kitchen.

Some studies have reported that agricultural workers received some training about handling pesticides and this has in turn improved their general practices and precautions. These studies have also found that even when agricultural workers possess the appropriate knowledge regarding how to handle pesticides, their families often keep engaging in dangerous and unhealthy practices around them (Coronado et al. 2012, Orozco et al. 2015). In this study, $68 \%$ of women had a husband working with pesticides, and
TABLE IV. PESTICIDE STORAGE AT HOME AMONG PARTICIPATING WOMEN $(n=47)$

\begin{tabular}{lc}
\hline Pesticides storage practices & Frequency (\%) \\
\hline Pesticides stored at home & 70 \\
Insecticide & 66 \\
Herbicide & 6 \\
Fungicide & \\
Use of pesticides at home & 79 \\
Domestic & 62 \\
Agricultural & 13 \\
For pets & \\
Specific location of pesticides at home & 98 \\
Special storage location & 68 \\
Outside the house & 28 \\
Storehouse & 21 \\
Exterior corridor & 17 \\
Around the house & 10 \\
Garage & 24 \\
Other & 32 \\
Inside the house & 36 \\
Bathroom & 21 \\
Living-dining room & 14 \\
Kitchen & 14 \\
Bedroom & 15 \\
Other & 34 \\
In the highest place in the room & \\
\hline
\end{tabular}

$62 \%$ of them came from a family of agricultural workers and lived with them in the same house. Thirty-eight percent of women were potentially more exposed, as a result of living with a family of agricultural workers and having a husband working in agriculture. Furthermore, women who were not directly engaged in agricultural work did not receive proper training regarding the handling of pesticides. As a result, women were not completely aware of the risks and necessary precautions involved in storing pesticides at home.

\section{Para-occupational exposure: women living in agricultural families}

Forty-eight women (62\% of participants) lived with an agricultural worker in the same house. A high percentage of women (92\%) reported that a family member commonly handled pesticides as part of their agricultural work (Table V). Women also received products grown in their fields; however they often wash them before consuming. Spraying and mixing pesticides are activities that involve a close contact with pesticides, and according to participants, these were performed by 79 and $63 \%$ of families, respectively. Regarding other practices among agricultural families, it was also common to leave their work boots outside the house. Moreover, $59 \%$ of 
agricultural workers used special clothes when working in the field, which were mostly washed at home by the women of the family. Fifty-eight percent of women washed the clothes of their husbands, and almost all husbands used pesticides as part of their daily work. In addition, none of the husbands wore coveralls for protection; therefore their clothes were contaminated with high levels of pesticides.

TABLE V. HANDLING PRACTICES OF WOMEN LIVING IN AGRICULTURAL FAMILIES $(\mathrm{n}=48)$

\begin{tabular}{lc}
\hline Practices & $\begin{array}{c}\text { Frequency } \\
(\%)\end{array}$ \\
\hline Use of pesticide by agricultural workers & 92 \\
Consumption of agricultural products & 85 \\
Washing of food from the field before consumption & 87 \\
Type of agricultural work done by family members & \\
Sowing & 85 \\
Spraying & 79 \\
Harvesting & 73 \\
Mixing pesticides & 63 \\
Helping an agricultural worker with his work & 31 \\
Harvesting & 67 \\
Sowing & 33 \\
Mixing pesticides & 7 \\
Spraying & 7 \\
Use of personal protection when participating in & \\
agricultural work & 27 \\
Leaves work boots outside the house by farmer & 75 \\
Use of special clothes for agricultural work & 59 \\
Place of washing the contaminated clothes & \\
Home & 95 \\
Field & 5 \\
Person who washes the contaminated clothes & \\
Participant & 75 \\
Daughter, mother, mother in law of farmer, & \\
laundress & 29 \\
Is an agricultural worker & 58 \\
Married & \\
Married with an agricultural worker & \\
Husband uses pesticides in his agricultural work & \\
\hline & \\
\hline
\end{tabular}

Comparative studies in the US have measured the risk of pesticide exposure at agricultural workers' houses and non-agricultural workers' houses living near agricultural zones. These studies have shown the presence of contaminated soil inside the houses of agricultural workers brought in through contaminated clothes, pesticide applicators, and vehicles used in the field (Simcox 1995, Curwin et al. 2007). Other studies addressed this issue focusing on children from agricultural families, highlighting the risk of living with contaminated clothes and shoes inside the houses (Curwin et al. 2007). These studies have suggested that children have a high risk of exposure to pesticides through contact with environmental contaminants on the floor as well as through hand-to-mouth behavior with dust and soil. The latter represents a significant source of pesticide exposure (Simcox et al. 1995, Castañeda-Yslas 2016). Furthermore, the results of the review by Deziel et al. (2015) found five studies with evidence of cleaning practices that had a potential impact on the concentration of pesticides in the dust at home. At the same time, none of these studies showed a proof of a correlation between cleaning practices and house dust.

\section{Para-occupational exposure: wives of agricultural workers}

Sixty-eight percent of the women in this study had a husband using pesticides as part of his daily work, and half of them were actually married to an agricultural worker using pesticides. Forty-nine percent of participants washed their husband's clothes by hand and only $29 \%$ used a laundry machine (Table VI). A high percentage of these women (86\%) washed these contaminated clothes separately from the rest, and only $10 \%$ mixed the contaminated clothes with her family's clothes. This frequency corresponds to the observations of the AHS (Gladen et al. 1998). Finally, only $5 \%$ of the women wore any sort of protection when washing the contaminated clothes of their husbands. Overall, these practices clearly represent a risky scenario for these women.

TABLE VI. PARA-OCCUPATIONALEXPOSURE OF WIVES OF WORKERS HANDLING PESTICIDES $(\mathrm{n}=50)$

\begin{tabular}{lc}
\hline Handling and washing of contaminated clothes & $\begin{array}{c}\text { Frequency } \\
\text { (\%) }\end{array}$ \\
\hline Washes by hand & 49 \\
Washes with laundry machine & 51 \\
Uses laundry machine only for this purpose & 0 \\
Use laundry machine for all family clothes & 29 \\
Uses non-automatic laundry machine for family & 31 \\
clothes & 86 \\
Washes the contaminated clothes separately & \\
Washes the contaminated clothes together whit & 10 \\
the family's & 5 \\
Uses personal protection when washing clothes & \\
\hline
\end{tabular}

\section{Commonly used agricultural pesticides}

Storing pesticides at home was a common practice in Muna. Forty-seven women (60\%) declared that pesticides were stored at their homes, and 30 of them could identify their common names (Table VII). 
TABLE VII. PESTICIDES USED BY FARMERS AND STORED AT HOME

\begin{tabular}{|c|c|c|c|c|c|}
\hline Common name & $\begin{array}{l}\text { Chemical } \\
\text { group }\end{array}$ & $\begin{array}{c}\text { WHO } \\
\text { classification }\end{array}$ & Usage & $\begin{array}{l}\text { Used by farmers } \\
(\%)(\mathrm{n}=38)\end{array}$ & $\begin{array}{c}\text { Stored at home }(\%) \\
(\mathrm{n}=30)\end{array}$ \\
\hline \multicolumn{6}{|l|}{ Insecticides } \\
\hline Methomyl & CAR & $\mathrm{Ib}$ & $\mathrm{A}, \mathrm{I}, \mathrm{L}, \mathrm{D}, \mathrm{U}$ & 61 & 38 \\
\hline Methamidophos & OP & $\mathrm{Ib}$ & $\mathrm{A}, \mathrm{I}$ & 53 & 21 \\
\hline Chlorpyrifos & OP & II & A, I, L, G, U & 47 & 17 \\
\hline Carbofuran & CAR & $\mathrm{Ib}$ & A, I & 42 & 7 \\
\hline Malathion & $\mathrm{OP}$ & III & A. I, L, G, U & 33 & 10 \\
\hline Parathion-methyl & OP & Ia & A, I & 33 & 14 \\
\hline Endosulfan & OCL & II & A, I & 31 & 7 \\
\hline Imidacloprid & I & II & A, I, L, U & 25 & 3 \\
\hline Diazinon & $\mathrm{OP}$ & II & A, I, L, D, G, U & 22 & 7 \\
\hline Lambda-cyhalothrin & PIR & II & A, L, U & 19 & 7 \\
\hline Cypermethrin & PIR & II & A, I, L, D, G, U & 17 & 7 \\
\hline Carbaryl & CAR & II & $\mathrm{A}, \mathrm{L}, \mathrm{I}$ & 14 & 3 \\
\hline \multicolumn{6}{|l|}{ Herbicides } \\
\hline Glyphosate & $\mathrm{P}$ & III & $\mathrm{A}, \mathrm{U}, \mathrm{G}$ & 78 & 41 \\
\hline $2,4-\mathrm{D}$ & $\mathrm{C}$ & II & A & 75 & 38 \\
\hline Paraquat & $\mathrm{B}$ & II & A, I & 86 & 69 \\
\hline Glufosinate & AS & II & $A, D, U, G$ & 39 & 14 \\
\hline Nicosulfuron & SU & $\mathrm{U}$ & A, I & 22 & 7 \\
\hline Picloram & $\mathrm{P}$ & $\mathrm{U}$ & A & 30 & 3 \\
\hline \multicolumn{6}{|l|}{ Fungicides } \\
\hline Mancozeb & $\mathrm{P}$ & $\mathrm{U}$ & A & 33 & 14 \\
\hline Captan & $\mathrm{C}$ & $\mathrm{U}$ & A & 31 & 3 \\
\hline Benomyl & $\mathrm{B}$ & $\mathrm{U}$ & $\mathrm{A}, \mathrm{I}$ & 22 & 22 \\
\hline Metalaxyl & $\mathrm{A}$ & II & $\mathrm{A}, \mathrm{I}, \mathrm{G}$ & 22 & 7 \\
\hline Chlorothalonil & $\mathrm{AP}$ & $\mathrm{U}$ & A & 17 & 3 \\
\hline Copper oxychloride & $\mathrm{CC}$ & II & $\mathrm{A}, \mathrm{I}, \mathrm{G}$ & 17 & 3 \\
\hline
\end{tabular}

CAR: carbamate, OP: organophosphorus, OCL: organochloride, I: imide, PIR: pyrethroids, P: fosfonometilglicine, C: chlorophenoxy, B: bipyridine AS: ammonium salts, SU: sulfonylurea, PI: pyridine, B: benzimidazole, AP: aromatic polychlorinated, C: carboxamide, A: aniline, CC: copper compounds, Ia: extremely hazard, Ib: highly hazard, II: moderately hazardous, III: slightly hazardous, A: agricultural, I: industrial, L: livestock, G: gardening, U: urban, D: domestic

Women also identified 25 different active ingredients used as pesticides by the agricultural workers: 12 insecticides, six herbicides, and six fungicides. Methomyl, methamidophos, and chlorpyrifos were the most used insecticides and stored by agricultural workers. Glyphosate, 2,4-D, and paraquat were the most used and stored herbicides in this community. Finally, mancozeb, captan, benomy, and metalaxyl were the most used and stored fungicides. All pesticides had an agriculture use; in contrast, only 17 $\%$ were for domestic use. Regarding the principal chemical groups, $21 \%$ of pesticides were organophosphorus (OP), $12 \%$ were carbamates (CAR), and $5 \%$ were pyrethroids (PIR). Half of the active ingredients were of class II (moderately hazardous) according to the World Health Organization
(WHO 2009), $13 \%$ were highly hazardous (class Ib), $8 \%$ were slightly hazardous (class III), $4 \%$ were extremely hazardous (class Ia), and $25 \%$ were indefinitely classified. This scenario shows that wives of agricultural workers in this community are exposed through a para-occupational pathway to a variety of active ingredients with different levels of toxicity, including highly toxic products. This situation appears similar to those described by other authors in North America (Gladen et al. 1998, Kirrane et al. 2004, Beard et al. 2013, Samanic et al. 2005) and the occupied Palestinian territories (Issa et al. 2010).

\section{Developing a pesticide exposure index (PEI)}

Figure 1 displays the accumulated frequency of the PEI score, dividing the population of this study 

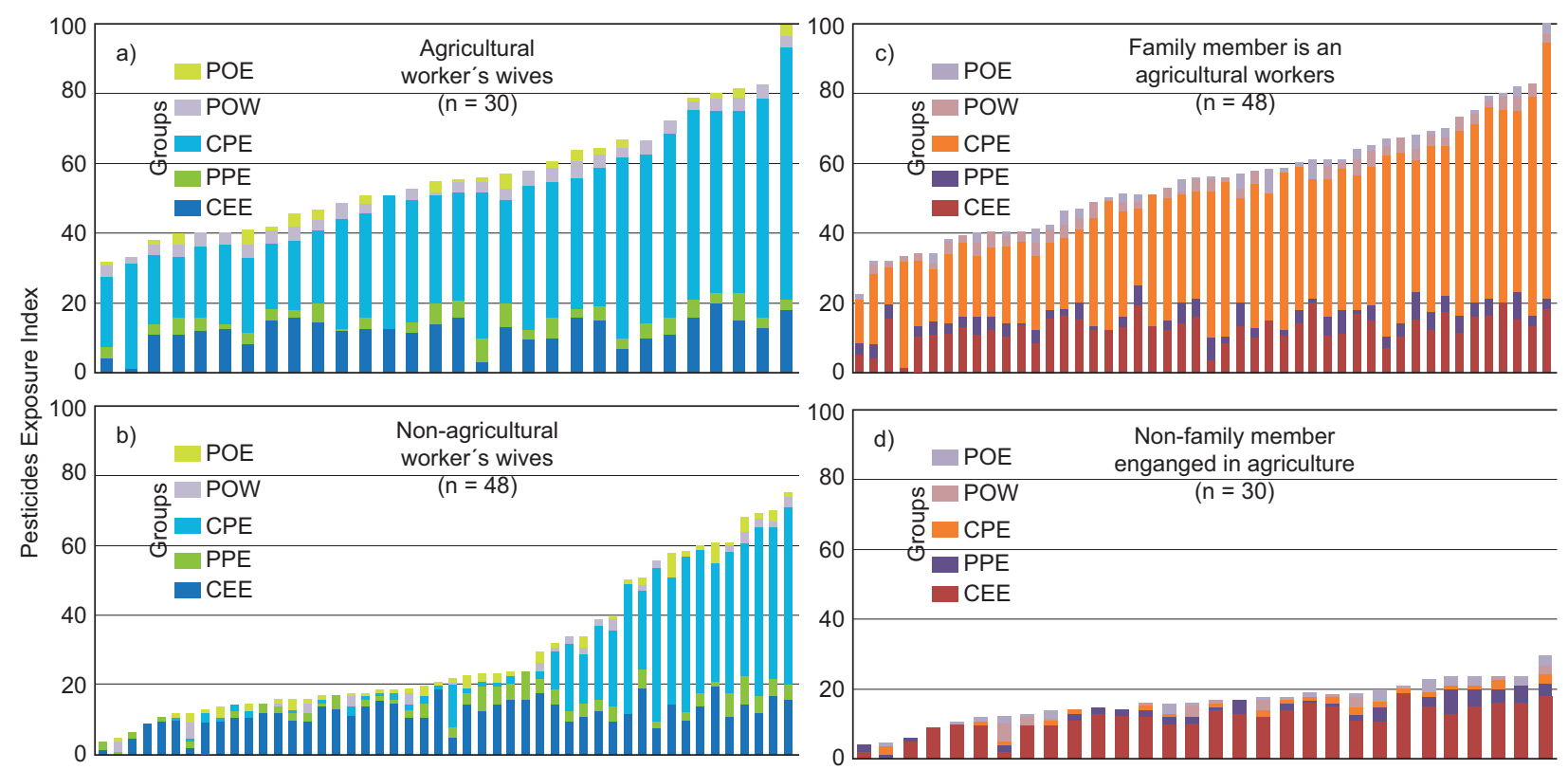

Fig. 1. Score frequency of pesticide exposure index by group. Groups: (a) agricultural worker's wives, (b) non-agricultural worker's wives, (c) family member is an agricultural worker, (d) non-family members engaged in agriculture. POE: past occupational exposure, POW: para-occupational exposure from washing contaminated clothes, CPE: current para-occupational exposure, PPE: past para-occupational exposure, CEE: current environmental exposure

in four groups: (1) wives of agricultural workers $(\mathrm{n}=30),(2)$ wives of non-agricultural workers ( $\mathrm{n}$ $=48)$, (3) members of an agricultural family $(\mathrm{n}=$ 48 ), and (4) members of a non-agricultural family $(\mathrm{n}=30)$. All participants had different values from 0 to 100 in the POE, POW, CPE, PPE, and CEE categories, which make up the PEI, which shows the presence of pesticide exposure in all the women in this study. CEE was present in all of them, regardless of the group, and like POE it is similar among women's groups. In women from non-agricultural families, CEE constituted the only pesticide exposure. In women from agricultural families we observed CEE along with CPE, although we found higher values of CEE as expected. CPE was observed in approximately $30 \%$ of women from non-agricultural workers. Finally, all agricultural workers' wives showed a high value of CPE as the main constituent of the PEI value.

Table VIII shows that PEI was significantly higher in wives of agricultural workers than in wives of non-agricultural workers. Similarly, women living in agricultural families had higher levels of exposure than those from non-agricultural families. In both cases, the difference was observed in the PPE, $\mathrm{CPE}$, and POW, showing that the past and current para-occupational exposure, as well as the activity of washing contaminated clothes of agricultural workers, constitutes the main difference in pesticide exposure in women of the study (Fig. 2).

Urine pesticide metabolites in populations show acute exposure. Moreover, a single measurement of urine metabolites could not reflect the magnitude of the chronic exposure. Some studies have shown the lack of correlation between urinary pesticide residue levels and long-term effects in populations chronically exposed to pesticides. Motsoeneng and Dalvie (2015) observed no association between neurotoxic symptoms and metabolites of OP in female agricultural workers from South Africa. Because of this, we have instead relied on the construction of variables as proxies to calculate the chronic pesticide exposure (Pérez-Herrera et al. 2008, Beard et al. 2013). Two limitations of this study - derived from convenience sampling - are the lack of knowledge about its precision and error and the limited extrapolations of data to other populations.

\section{CONCLUSIONS}

This study shows the participants in our survey showed a complex scenario of pesticide exposure and have multiple direct and indirect pathways of 
TABLE VIII. COMPARISON OF PEI SCORE PER GROUP

\begin{tabular}{|c|c|c|c|c|c|c|c|}
\hline \multirow[b]{2}{*}{$\begin{array}{l}\text { Index/ } \\
\text { categories }\end{array}$} & \multirow[b]{2}{*}{$\begin{array}{l}\text { All participants } \\
\quad(\mathrm{n}=78)\end{array}$} & \multicolumn{6}{|c|}{ Groups (n) } \\
\hline & & $\begin{array}{l}\text { Agricultural } \\
\text { worker's wives } \\
\quad(\mathrm{n}=30)\end{array}$ & $\begin{array}{l}\text { Non-agricultural } \\
\text { worker's wives } \\
\quad(n=48)\end{array}$ & $p$ & $\begin{array}{c}\text { Family member is } \\
\text { an agricultural } \\
\text { worker } \\
(\mathrm{n}=48)\end{array}$ & $\begin{array}{l}\text { Non-family mem- } \\
\text { bers engaged in } \\
\text { agriculture } \\
(\mathrm{n}=30)\end{array}$ & $p$ \\
\hline PEI & $40.2 \pm 22.9^{\mathrm{a}}$ & $55.3(31.8-99.9)^{\mathrm{b}}$ & $21.5(4-74.9)^{\mathrm{b}}$ & $<0.001^{1 *}$ & $55 \pm 16.1^{\mathrm{a}}$ & $16.5 \pm 5.9^{\mathrm{a}}$ & $<0.001^{2^{*}}$ \\
\hline CEE & $11.9(0-19.9)^{\mathrm{b}}$ & $12.9(1.2-19.98)^{\mathrm{b}}$ & $11.9(0-19.9)^{\mathrm{b}}$ & $0.781^{1}$ & $12.9(1.2-19.9)^{\mathrm{b}}$ & $11.9(0-18.9)^{\mathrm{b}}$ & $0.401^{1}$ \\
\hline PPE & $3 \pm 2^{\mathrm{a}}$ & $3.5(0-8)^{b}$ & $2(0-8)^{b}$ & $0.016^{1^{*}}$ & $4(0-8)^{b}$ & $2(0-7)^{b}$ & $<0.001^{1 *}$ \\
\hline $\mathrm{CPE}$ & $20(0-73)^{b}$ & $33(17-73)^{b}$ & $1.5(0-51)^{\mathrm{b}}$ & $<0.001^{1 *}$ & $35.5(11-73)^{b}$ & $1(0-3)^{b}$ & $<0.001^{1 *}$ \\
\hline POW & $2(0-5)^{\mathrm{b}}$ & $3.5(0-5)^{\mathrm{b}}$ & $0(0-5)^{\mathrm{b}}$ & $<0.001^{1 *}$ & $3(0-5)^{\mathrm{b}}$ & $0(0-5)^{b}$ & $<0.001^{1^{*}}$ \\
\hline POE & $1(0-7)^{b}$ & $1(0-4)^{\mathrm{b}}$ & $1(0-7)^{b}$ & $0.759^{1}$ & $1(0-7)^{b}$ & $1(0-4)^{b}$ & $0.914^{1}$ \\
\hline
\end{tabular}

PEI: pesticide exposure index, CEE: current environmental exposure, PPE: past para-occupational exposure, CPE: current para-occupational exposure, POW: para-occupational exposure from washing contaminated clothes, POE: past occupational exposure

${ }^{\mathrm{a}}$ Mean \pm standard deviation, ${ }^{\mathrm{b}}$ median (minimum - maximum)

${ }^{1} \mathrm{p}$ Mann-Whitney $\mathrm{U}$ test, ${ }^{2} \mathrm{p}$ Student $\mathrm{t}$ distribution test

*Significant at $\mathrm{p}<0.05$

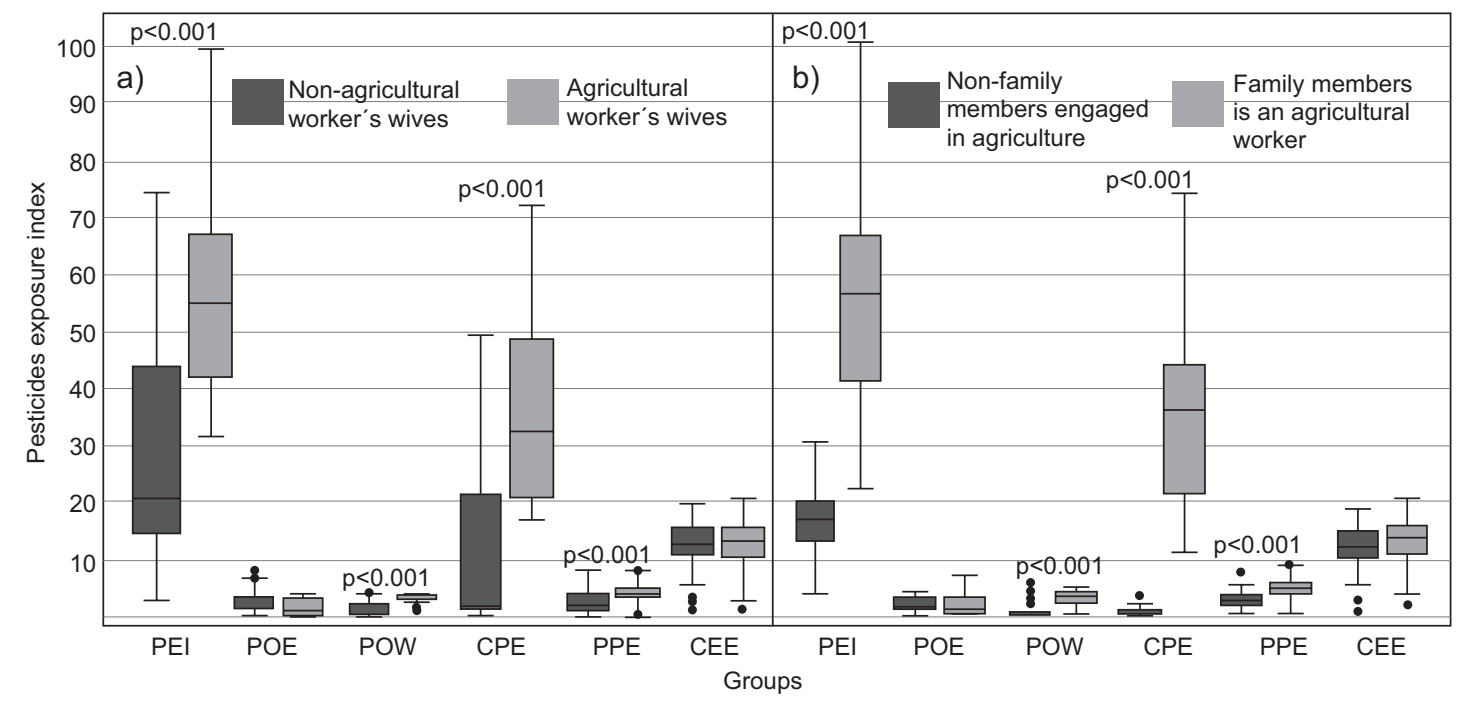

Fig. 2. Distribution of pesticide exposure index and comparison within categories and groups. Groups: (a) agricultural worker's wives $(n=38)$ and non-agricultural worker's wives $(n=48),(b)$ family member is an agricultural worker $(\mathrm{n}=48)$ and non-family members engaged in agriculture $(\mathrm{n}=30)$. PEI: pesticide exposure index, POE: past occupational exposure, POW: para-occupational exposure from washing contaminated clothes, CPE: current para-occupational exposure, PPE: past para-occupational exposure, CEE: current environmental exposure

exposure. Through an exposure index, we showed that women living in an agricultural community have inherently certain degree of environmental exposure to pesticides. Moreover, with the construction of a PEI, we also demonstrated that women living in a family of agricultural workers (especially the wives of agricultural workers) face an important type of para-occupational pesticide exposure caused by the activities of their relatives and husbands. Overall, this work shows that we should not underestimate the degree of pesticide exposure of women who are not directly engaged in agricultural works.

\section{ACKNOWLEDGMENTS}

The authors want to express their gratitude to the Red Temática de Toxicología de Plaguicidas 
(CONACyT-262284/280045/294303), the participants in this study and the kind help of Pablo Aguilera del Castillo. This study was financed by the PROMEP-SEP.

\section{REFERENCES}

Alavanja M.C., SandlerD.P., McMaster S.B.,Zahm S.H., McDonnell C.J., Lynch C.F., Pennybacker M., Rothman N., Dosemeci M., Bond A.E. and Blair A. (1996). The agricultural health study. Environ. Health Perspect. 104 (4), 362-369.

Beard J.D., Hoppin J.A., Richards M., Alavanja M.C.R., Blair A., Sandler D.P. and Kamel F. (2013). Pesticide exposure and self-reported incident depression among wives in the agricultural health study. Environ. Res. 126, 31-42.

DOI: 10.1016/j.envres.2013.06.001

Castañeda-Yslas I.J., Arellano-García M.E., García-Zárate M.A., Ruíz-Ruíz B., Zavala-Cerna M.G. and TorresBugarín O. (2016). Biomonitoring with micronuclei test in buccal cells of female farmers and children exposed to pesticides of Maneadero agricultural valley, Baja California, Mexico. J. Toxicol 2016, 1-8.

DOI: $10.1155 / 2016 / 7934257$

Coronado G.D., Holte S.E., Vigoren E.M., Griffith W.C., Barr D.B., Faustman E.M. and Thompson B. (2012). Do workplace and home protective practices protect farm workers? Findings from the "For Healthy Kids" study. J. Occup. Environ. Med. 54(9), 1163-1169. DOI: $10.1097 / J O M .0 b 013 \mathrm{e} 31825902 \mathrm{f5}$

Curwin B.D., Hein M.J., Sanderson W.T., Striley C., Heederik D., Kromhout H., Reynolds S.J. and Alavanja M.C. (2007). Pesticide dose estimates for children of Iowa farmers and non-farmers. Environ. Res. 105(3), 307-315. DOI: 10.1016/j.envres.2007.06.001

Deziel N.C., Friesen M.C., Hoppin J.A., Hines C.J., Thomas K. and Beane Freeman L.E. (2015). A review of nonoccupational pathways for pesticide exposure in women living in agricultural areas. Environ. Health Perspect. 123(6), 515-524. DOI: 10.1289/ehp. 1408273

Gladen B.C., Sandler D.P., Zahm S.H., Kamel F., Rowland A.S. and Alavanja M.C.R. (1998). Exposure opportunities of families of farmer pesticide applicators. Am. J. Ind. Med. 34(6), 581-587. DOI: 10.1002/(SICI)10970274(199812)34:6<581::AID-AJIM6>3.0.CO;2-U

INEGI (2010). Información nacional, por entidad federativa y municipios. Instituto Nacional de Estadística y Geografía [en línea]. http://www.inegi.org.mx/ sistemas/mexicocifras/default.aspx? $\mathrm{e}=31$ 21/08/2012

Issa Y., Sham'a F.A., Nijem K., Bjertness E. and Kristensen P. (2010). Pesticide use and opportunities of exposure among farmers and their families: cross-sectional studies 1998-2006 from Hebron governorate, occupied Palestinian territory. Environ. Health. 9(1), 63.

DOI: 10.1186/1476-069X-9-63

Jurewicz J., Hanke W., Sobala W. and Ligocka D. (2012). Exposure to phenoxyacetic acid herbicides and predictors of exposure among spouses of farmers. Ann. Agr. Env. Med. 19, 51-56.

Kirrane E.F., Hoppin J.A., Umbach D.M., Samanic C. and Sandler D.P. (2004). Patterns of pesticide use and their determinants among wives of farmer pesticide applicators in the agricultural health study. J. Occup. Environ. Med. 46(8), 856-865.

DOI: 10.1097/01.jom.0000135521.15169.3e

Lerro C.C., Koutros S., Andreotti G., Friesen M., Alavanja M.C., Blair A., Hoppin J.A., Sandler D.P., Lubin J.H., Ma X., Zhang Y. and Beane Freeman L.E. (2015). Organophosphate insecticide use and cancer incidence among spouses of pesticide applicators in the Agricultural Health Study. Occup. Environ. Med. 72(10), 736-744.

DOI: 10.1136/oemed-2014-102798

Montgomery D.C., Peck E.A. and Vinnig G.G. (2006). Introducción al análisis de regresión lineal. 3a ed. Compañía Editorial Continental, México, 237 pp.

Mostafalou S. and Abdollahi M. (2013). Pesticides and human chronic diseases: Evidences, mechanisms, and perspectives. Toxicol. Appl. Pharm. 268(2), 157-177. DOI: 10.1016/j.taap.2013.01.025

Motsoeneng P.M. and Dalvie M.A. (2015). Relationship between Urinary pesticide residue levels and neurotoxic symptoms among women on farms in the Western Cape, South Africa. Int. J. Environ. Res. Pub. He. 12(6), 6281-6299.

DOI: $10.3390 /$ ijerph120606281

Orozco F., Mota E.L. and Cole D.C. (2015). Social capital and health information in the context of small scale farmers' livelihoods. Salud Colect. 11(2), 177-189. DOI: $10.1590 / \mathrm{S} 1851-82652015000200003$

Pérez-Herrera N., Castillo-Burguete M., Vera-Avilés M., Alvarado-Mejía J. and Quintanilla-Vega B. (2013). Investigación-acción participativa con una comunidad agrícola de Yucatán. Memorias. IX Congreso Nacional de Toxicología. Nuevo Vallarta, Nayarit. 5 al 8 de noviembre, 2013. 136.

Pérez-Herrera N., May-Pech C., Hernández-Ochoa I., Castro-Mañé J., Rojas-García E., Borja-Aburto V.H., Castillo-Burguete T. and Quintanilla-Vega B. (2008). PON1Q192R polymorphism is associated with lipid profile in Mexican men with Mayan ascendancy. Exp. Mol. Pathol. 85(2), 129-134.

DOI: 10.1016/j.yexmp.2008.05.003 
Romero M., Rodríguez E.M., Durand-Smith A. and Aguilera R.M. (2003). Veinticinco años de investigación cualitativa en salud mental y adicciones con poblaciones ocultas. Primera parte. Salud Mental 26(6), 76-83.

Saavedra Solano N., Berenzon Gorn S. and Galván Reyes J. (2016). Salud mental y atención primaria en México. Posibilidades y retos. Aten. Primaria 48(4), 258-264. DOI: 10.1016/j.aprim.2015.05.005

Samanic C., Hoppin J.A., Lubin J.H., Blair A. and Alavanja M.C.R. (2005). Factor analysis of pesticide use patterns among pesticide applicators in the Agricultural
Health Study. J. Expo. Anal. Environ. Epidemiol. 15, 225-233. DOI: 10.1038/sj.jea.7500396

Simcox N.J., Fenske R.A., Wolz S.A., Lee I.C. and Kalman D.A. (1995). Pesticides in household dust and soil: exposure pathways for children of agricultural families. Environ. Health Perspect. 103(12), 1126-1134.

WHO (2009). The WHO Recommended Classification of Pesticides by Hazard and Guidelines to Classification 2009 [en línea]. http://apps.who.int/iris/bitstream/10665/ 44271/1/ 9789241547963_eng.pdf 27/08/2017. 